\title{
Donors and Esoteric Buddhism in Dunhuang during the Reign of the Guiyijun
}

\author{
Henrik H. Sørensen
}

\section{Introduction}

Our current understanding of Buddhism at Dunhuang (敦煌) is especially well-informed for the period when Dunhuang was under the control of the Guiyijun (851-1036?, 歸義軍, Return-to-Allegiance Army) regime, which ruled over Shazhou (沙州) and neighbouring Guazhou (瓜州) for a period covering nearly two centuries. ${ }^{1}$ The primary sources, most of which were recovered from the celebrated Mogao Cave (Chin. Mogao ku 莫高窟) 17, contain a plethora of information on virtually all aspects of religious and secular life at Dunhuang, and on Buddhism in particular, during the period in question. However, even though we have been graced with numerous studies on so many aspects of Buddhism in the oasis town and at the Mogao Caves, there are still many questions and issues that wait to be answered. Among these is a more detailed and precise understanding of the relationship between the local population and Buddhist beliefs, especially what kind(s) of Buddhism were practiced in Shazhou during the Guiyijun period, and how this played out on the ground. Many scholars have discussed the extent to which lay Buddhist patrons supported Buddhism. In recent years, issues relating to the economy and material production in connection with Buddhist institutions have been popular themes, especially in studies by Chinese Mainland scholars, some even going so far as to refer to Buddhism during the Guiyijun period as 'secular Buddhism.'2 Even so, we still need to better understand which forms of Buddhism were

1 For a survey of the relationship between Buddhism and the local government at Dunhuang during this period based on primary sources, see Henrik H. Sørensen, "Guiyijun and Buddhism at Dunhuang: A Year by Year Chronicle," BuddhistRoad Paper 4.2 (2019). See also Rong Xinjiang 榮新江, Guiyijun shiyanjiu 歸義軍史㗏究 [A Study of the History of the Guiyijun], Zhongguo chuantong wenhua yanjiu congshu (Shanghai: Shanghai guji chubanshe, 1995).

2 See for instance, Hao Chunwen 郝春文, Tang houqi Wudai Song chu Dunhuang seng ni de shehui shenghuo 唐后期五代宋初敦煌僧尼的社会生活 [The Social Life of Buddhist Monks and Nuns in Dunhuang during the Late Tang, Five Dynasties period and the Early Song] (Beijing: Zhongguo shehui kexue chubanshe, 1998). It goes without saying that it is the author's Socialist approach to Buddhism, and religion as a whole, which leads to his ideas of 
prevalent in Dunhuang and why they were found particularly attractive by patrons. Surely there were many reasons why Buddhism had such an allure for people from all walks of life in the oasis - more than can be covered in a single paper such as this. Nevertheless, we may assume that the manner in which Buddhist beliefs and practices were formulated at Dunhuang during the Guiyijun reign was hardly coincidental, nor a result of randomness. Clearly it happened for certain reasons, which are necessary to understand if we want to go beneath the colourful surface of Buddhist life at Dunhuang during the gth to 1oth centuries.

In this essay, I account for the relationship between donor portraits-or rather, self-presentations by Buddhist donors, as represented in Buddhist votive paintings from Dunhuang during the Guiyijun reign period-and those Buddhist cults depicted in said paintings. A closer look at these paintings and their donors indicates that an analysis of this relationship may provide us with more clear ideas of exactly what kinds of Buddhism were practised by the local clans in Shazhou (and by extension, Guazhou) during the period in question, and what this reveals about Buddhism in the western-most part of the Hexi Corridor (Chin. Hexi zoulang 河西走廊) and further west. Given that most of the donors portrayed in the paintings belong to the important, major clans in Shazhou, it goes without saying that the material under discussion here to a large extent reflects Buddhism and elite culture. In order to achieve the objective outlined above, I selected a number of paintings that feature such donor portraits, which may inform us of the Buddhist practices that lay behind their imagery and production.

a 'secular Buddhism.' From such a perspective all religion appears secular-to a greater or lesser degree-since virtually all of them participated in and were infused with so-called secular life. The gist of this book can be found in Hao Chunwen, "The Social Life of Buddhist Monks and Nuns in Dunhuang during the late Tang, Five Dynasties, and Early Song," Asia Major Third Series 23.2 (2010): 77-95; Chen Ming and Zhao Zhiling, "Fojiao renjian jingshen de huigui yu fo ku gongneng de zhuanbian-Guiyijun shiqi Dunhuang fojiao de jiben tezheng 佛教人間精神的回歸與佛窟功能的轉變一歸義軍時期敦煌佛教的基本特徵 [The Return of the World Spirit of Buddhism and the Transformation of the Functions of Buddha Caves: Basic Features of Buddhism in Dunhuang During the Guiyijun Period]," Cross-cultural Communication 4.2 (2008): 41-47. Although not ideologically handicapped like Hao, the Chinese scholar Ning Qiang (寧強) operates consistently with a dual model in which a distinction is made between 'religious practitioners' on the one hand and 'secular donors' on the other, indicating that there were major differences between the ways the two groups understood and practiced Buddhism. Even though such distinctions may be meaningful as a manner of dealing with different categories of Buddhist practitioners, it is not overly useful as a way of understanding differences or degrees in relation to religious practice. Cf. Ning Qiang, Art, Religion and Politics in Medieval China: The Dunhuang Cave of the Zhai Family (Honolulu: University of Hawai'i Press, 2004), 5, 121, 133. 
Before proceeding, it is important to note that the Esoteric Buddhist beliefs and practices behind much of the icon production encountered in Dunhuang during the 9th-1oth centuries, were overwhelmingly concerned with the cults surrounding the Bodhisattva Avalokiteśvara in his various forms. This observation - trivial as it may seem - is actually important, as we shall presently see, especially since it contributes to an understanding of the relationship between Buddhist donors and Esoteric Buddhism. It is also clear, at least for the surviving material from Cave 17, that there are no surviving icons which unmistakably reflect the presence of Tibetan Buddhism and its Tantric dispensation during the 1oth century, neither directly nor indirectly. ${ }^{3}$ I would also like to stress that the present study is not conducted from the perspective of Chinese Buddhist art history per se, but rather from the interface between religion, material culture, and history.

\section{Buddhist Donors and Paintings at Dunhuang}

Before embarking on a discussion of the primary issue defined above, there are a few points which need to be made regarding the production of religious artefacts and their sponsors, i.e. the Buddhist patrons and donors who commissioned them. ${ }^{4}$ Buddhist patrons in Dunhuang during the 1oth century come in a variety of types and hail from virtually all walks of life. As such they account for the members of the highest echelons of Dunhuang's society-including rulers and the important local clans-as well as merchants, farmers, artisans, etc., and foreigners, whether settled locally or travellers more generally defined. Moreover, Buddhist donors include Buddhist monastics as well as ordinary citizens. Since the Buddhist icons discussed here reflect the existence of thriving local cults in nearly all instances, we are justified in reading them as material expressions of their popularity during the time in question.

3 There are only a handful of banner paintings and line drawings among the entire hoard, which reflect the presence of early Tibetan Buddhist art, i.e. MG 1148, MG 1131, MG 26466, OA 1919,O101,O.16o, 1919,O101,O.5o, OA 1919,o101,O.137, OA 1919,o101,o.101, OA 1919,o101,o.102, OA 1919,0101,0.103, etc. Possibly even OA 1919,0101,0.57R should be seen as an early example of a Tibetan Buddhist painting done under strong Chinese influence. Surely all of these date from the period when Dunhuang was under Tibetan rule, i.e. from between 78 os to the mid9th century. The same can be said about the wall paintings in the caves. Very few have been identified as from the period of Tibetan rule, and in any case all of these are in Chinese style, indicating that there were none or very few Tibetan artisans skilled in the production of Buddhist art working in Dunhuang during the 8th-9th centuries.

4 See Henrik H. Sørensen, "The Practice of Giving: Buddhist Donors and Donor Dedications from 1oth Century Dunhuang," BuddhistRoad Paper 4.3 (2019). 
The votive paintings (also referred to as banner paintings) that form the basis of this study come in a great variety of qualities and themes. Some were clearly produced for members of the local elite, whereas others reflect less affluent donors. All of them have in common the presence inside the picture frame of portraits of the donors who had them made as offerings to be dedicated to the local Buddhist establishments. This penchant for inserting representations of one's self into a holy icon reflects a new trend in Chinese Buddhist art, in which both a visual and textual record of the act of giving becomes almost as important as the deity depicted in the icon itself. One concrete way we see this change in relation to icon production is in the growing sizes of the donor portraits vis-à-vis the deity depicted, which in some cases take up nearly as much space within the painting as that allotted to the given Buddha or bodhisattva. ${ }^{5}$ In this regard, it should also be noted that the votive paintings found in Dunhuang are in many ways typologically unique from the perspective of Chinese Buddhist iconography. While this material is often taken as representative of Later Tang Dynasty (923-935, 後唐) and Five Dynasties (906-978, 五代) Buddhist art in China per se, few seem to realise that these paintings represent a specialised form of Buddhist art that is very much localised. In fact, this form is not documented anywhere else, with the possible exception of stylistic remnants reflected in pictorial material found at the Uyghur Buddhist sites in and around Turfan. And of course, there is virtually nothing comparable to the votive or banner paintings that survives from anywhere else in China. This makes the Dunhuang paintings a unique cache of religious art, even if we sometimes encounter similar, individual forms and typologies in the art of East Asian more broadly defined. ${ }^{6}$

While we find a considerable number of different icons represented in the Buddhist paintings from Dunhuang, one type of motif overshadows them all, and that is depictions of the various forms of Avalokiteśvara. The votive paintings alone feature as many as twenty different forms, excluding the numerous variants, with the most significant representatives of the Esoteric Buddhist pantheon being the Thousand-armed, Thousand-eyed Avalokiteśvara

5 For a discussion of this, see Henrik H. Sørensen, "Donors and Image at Dunhuang: A Case Study of OA 1919,0101,0.54," BuddhistRoad Paper Series 4.1 (2019). See also the recent discussion in Niel Schmid, "The Material Culture of Exegesis and Liturgy and a Change in the Artistic Representations in Dunhuang Caves, ca. 700-1000," Asia major 19.1-2 (2017): 171-210.

6 For instance, certain forms of deities and protectors, such as Mahākāla, Śiva, vajrapālas, lokapālas, etc., that are evident in the Dunhuang paintings, can be found in surviving examples from the Japanese Heian period (794-1185, 平安時代). See Henrik H. Sørensen, “Typology and Iconography in the Esoteric Buddhist Art of Dunhuang," Silk Road Art and Archaeology 2 (1991-1992):285-349. Although this survey is now slightly outdated, many of the observations presented there are still relevant. 
(standing and sitting), Ekādaśamukhāvalokiteśvara (standing and sitting), Amoghapāśa (standing and sitting), Cintāmaṇicakrāvalokiteśvara, Mahāpratisāra, and to a lesser extent, Padmapāni. Moreover, there are many examples of all of these forms, underlying the importance of not only the general cult of Avalokiteśvara as pre-eminent among the Buddhist saviour deities, but also the proliferation of the cults of his different aspects. What follows is in large measure a reflection of this popularity, one which Buddhism in Dunhuang shared with the rest of medieval China.

\section{Thousand-Armed Avalokiteśvara (MG 17659)}

The cults associated with the various forms of Avalokiteśvara are central to the discussion of donors and Esoteric Buddhism in Dunhuang during the period of Guiyijun rule. But none of them are quite as important as Sahasrabhuja-sahasranetra, i.e. the Thousand-eyed and Thousand-armed Avalokiteśvara. There are a plethora of paintings on this theme, in the form of scrolls and wall paintings, as well as smaller images painted on paper, probably for commercial distribution. To some extent, this popularity is also reflected in surviving manuscripts of the Nïlakanthakasūtra (T. 1060.20, T. 1056.20, T. 1061.20, etc.) and its related liturgical texts. ${ }^{7}$ Interestingly, the Tibetan manuscripts from Dunhuang also reflect the importance of this cult. ${ }^{8}$

As it is impossible within the scope of a single presentation to account for all the various examples of paintings of the Thousand-eyed Avalokiteśvara, I selected one of the most representative paintings, namely MG 17659. It is a tripartite painting with Avalokiteśvara as the main icon and a much smaller depiction of Kșitigarbha in the bottom right corner, facing the portrait of the donor on the left, who is shown standing with his entourage behind him (fig. 4.1).

The male donor of this painting is identified as Fan Jishou (fl. 1oth century, 㡑繼壽), the second part of which means something like 'Succession of Longevity', and is in all likelihood a styled name. We do not know who this person is, but surely he was a prominent gentleman belonging to the highest echelon of Dunhuang society, possibly directly related to the Cao (曹) rulers, since he is

7 Cf. e.g. OA 1919,0101,0.35, OA 1919,0101,0.159, MG 17775, etc.

8 See Sam van Schaik, "The Tibetan Avalokitesvara Cult in the Tenth Century: Evidence from the Dunhuang Manuscripts," in Tibetan Buddhist Literature and Praxis, ed. Ronald M. Davidson and Christian Wedemeyer (Leiden: Brill, 2006), 55-72. 


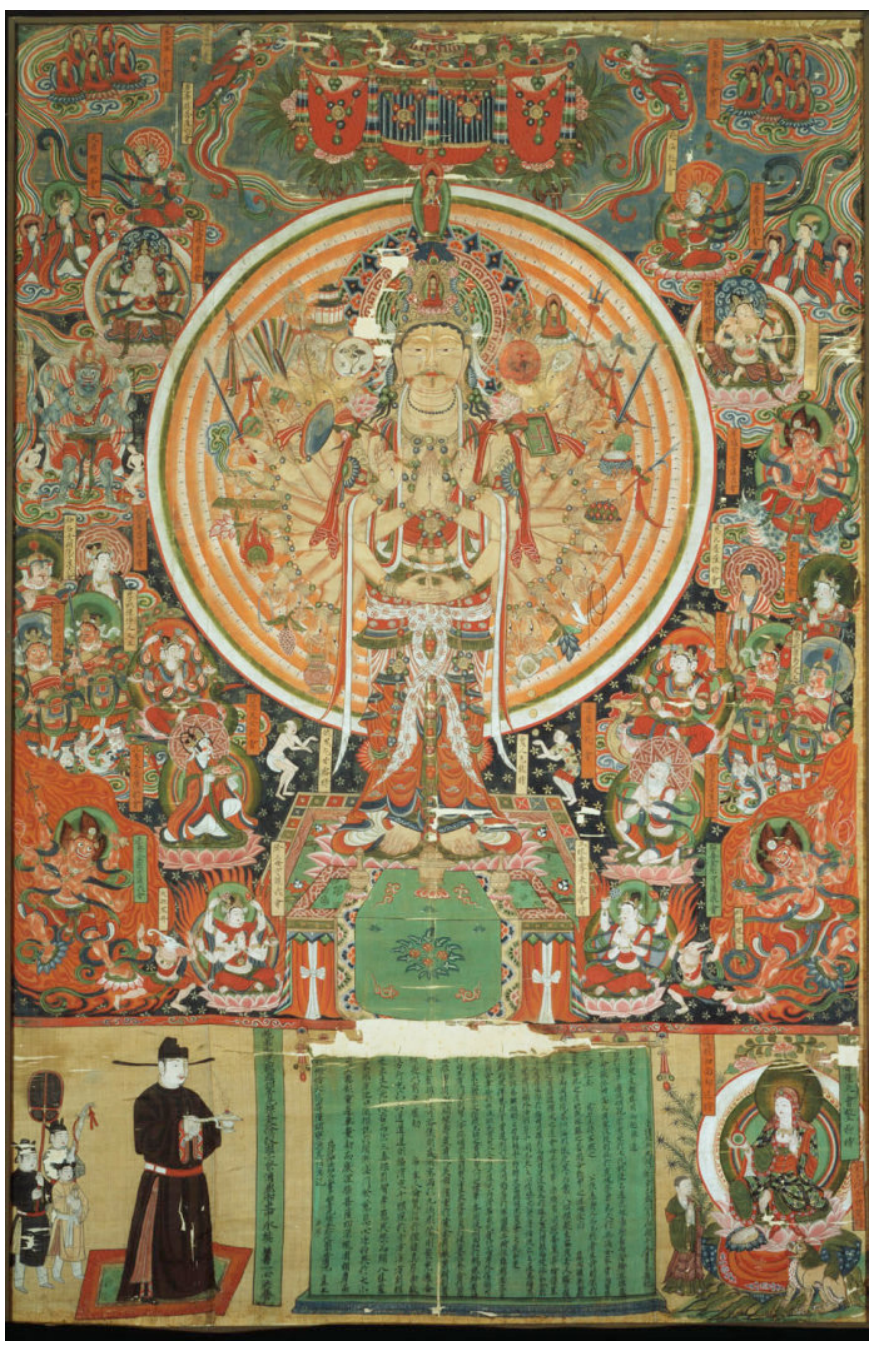

FIGURE 4.1 The Thousand-armed Avalokiteśvara. Dunhuang, 10th c. MG 17659.

referred to in the inscription as District Governor (Chin. du jiedu 都節度). ${ }^{9}$ In

9 In addition, one may add in support of the view that Fan Jishou belonged to the nobility, that the quality of the painting indicates that it was obviously commissioned by a wealthy person. If we look at the context in which the painting in question was produced, we are looking for someone belonging to the highest levels of society, a government official and military man, and one who lived in or around 980 . As it is, there is only one other reference to a Fan Jishou in the Dunhuang material, in which the last part of the name is written with a different character, namely a private letter $\left(\mathrm{P} .4518 \mathrm{~V}^{\circ}(11)\right)$. If indeed this is the 
this case, the text of the donor dedication is lengthy and detailed, and although it is couched in the usual hyperbolic phraseology common to official and formal documents, it does feature a number of concrete facts regarding how the donor (or the composer of the dedication) envisaged the cult of the Thousand-armed Avalokiteśvara. Therefore, let us take a closer look at how the donor dedication written by a Fan Yanxing, (fl. Second half of 1oth century, 氾 彥興) expresses Fan Jishou's devotion:

[...] Subaltern of the Military Government (Chin. jidu yaya 節度押衙), Overseer and Secretary, Great Person of Silver-Green Bright Prosperity, Examining Officer [i.e. censor], Son of the Nation, Sacrificer of Alcohol, Fan Yanxing, (fl. Second half of 1oth century, 氾彥興) reports that he has heard of the vow of the Great Compassion (大悲 $)^{10}$ [that he alleviates] severe transgressions of innumerable kalpas, as well as his rejection [to enter] nirvāna [for himself, signs that] the bodhisattva's virtue is deep. He manifests in corporal form in the world, opening upāyas (Chin. kaifangbian 開方便) according to [peoples'] roots and discourses on the sudden and gradual dharma methods (Chin. dunjian famen 頓漸法門), giving rise to a mind of compassion, case by case, and through big and small transformations, [such as] being born and dying, entering death, [in order to] uproot suffering and eliminate the Three Poisonous Roots (Chin. sandu gen 三毒根) [of hate, desire and ignorance]. He guides with wisdom the ignorant to bliss by [making them] revert to the Eight Victorious Levels (Chin. bashengchu 八勝處) ${ }^{11}$ [where they will] obtain the ten thousand practices, and satisfy all [sentient beings] in the Six Paths [of rebirth]. Accordingly, in all the destinies, the merit will then eliminate the calamities, and his thousand eyes will illumine all of the ten directions, each of which will then have their darkness illumined $[. . .]^{12}$

actual name of the donor in the painting, it is somewhat peculiar that we do not have more information on this person, as he was obviously a man of considerable importance, not only because of his titles, but also because of the way he appears in the painting. As is discussed elsewhere in this study, such a manner of portraying high ranking donors was reserved for the Cao kings and members of their immediate family.

10 A common epithet for Avalokiteśvara.

11 These refers to the levels of mastery of desire as undertaken by Buddhist adepts.

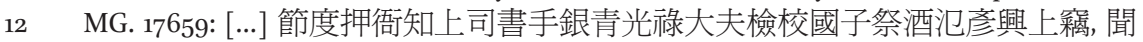
大悲願重過無量劫, 而厭涅菩薩功深現有相身, 而世界進方便口隨根說於頓漸 法門, 發慈悲心逐物興於大小變出生入死拔苦, 而除三毒根引智牽愚興樂, 而歸 八勝處得萬行. 充於六道道道, 則福消災, 千眼照於十方, 方方則明暗 [...]. 
We see here the typical adoration and devotion to Avalokiteśvara as the preeminent bodhisattva of Chinese Buddhism, rather than an indication of the donor's formal affiliation with Esoteric Buddhism per se. There is of course, a reason why this particular iconographical motif was chosen, and one may speculate that the gentleman portrayed was indeed sufficiently appraised of the instructions found in the Nilakanțhaka-sütra, the primary source on the Esoteric Buddhist cult of the Thousand-armed Avalokiteśvara. ${ }^{13}$

A characteristics of the Buddhist banner paintings from Dunhuang is a composition with different pictorial divisions within the same painting, a feature which became especially noteworthy_perhaps even popular-during the 1oth century. In connection with these paintings that combine discrete iconographical themes, it is noteworthy that a few of them include renderings of both Avalokiteśvara and Kșitigarbha. ${ }^{14}$ This is what we see here, where Kșitigarbha appears as a secondary icon in the painting. Exactly what connection there was between what were ostensibly two distinct cults, not to mention the relationship between the Thousand-armed Avalokiteśvara, a major Esoteric Buddhist divinity, and Kșitigarbha, who is primarily associated with the tribunals of the Netherworld, is unclear. However, given that they represent the two primary saviour bodhisattvas in Chinese Buddhism par excellence, it is perhaps a logical artistic and conceptual step to include both in the same painting.

Although the royal-looking donor figure in this painting remains unidentified, I venture the opinion that the image actually portrays one of the Cao princes. Although the cartouche with his name and the dedication of the painting as an offering has not been rendered in the shape of a pillar, as is otherwise common for portraits of royalty in Dunhuang under the Guiyijun, there can be little doubt that this is a portrait of someone from the ruling elite. Note the attendants standing behind the donor, who carry the formal insignia of a high government official. Therefore our Fan Jishou may be identical with one of the Cao rulers, or even more likely, a Cao prince. Hence, I am inclined to read the name as a styled name, indicating that Fan Jishou may have been a son of Cao Yanlu 曹延祿 (r. 976-1002), but in any case was someone closely related to the royal family.

13 Another copy of the Nïlakanțhaka-sūtra is found in S. 3793, translated by Bhagavaddharma in Khotan in the 7 th century. This is the same version found in T. 1060.20.

14 For an example of this, see MG 3644. 
Ekādaśamukha is another popular Esoteric Buddhist form of Avalokiteśvara, depictions of which occur with a relatively high frequency among the Buddhist paintings at Dunhuang. As with the Thousand-armed form, which in historical perspective actually derived iconographically as well as textually from Ekādaśamukha, there are several surviving examples of this image among the banner paintings, most of which include donor portraits and dedications. One such painting is preserved in the Harvard Art Museum (1943.57.14). Although representations of Ekādaśamukha tend to be depicted in slightly different ways, it is clear that the Ekādaśamukhadhāranīsūtra (T. 1070.20) served as the basic iconographical model.

The painting depicts Ekādaśamukhāvalokiteśvara in standing form with six arms (fig. 4.2). Surrounding him are scenes illustrating his role as saviour from perils, each identified by a corresponding text set in a red cartouche, a convention of the so-called scriptural tableaux (Chin. jingxiang 經相), and a feature that also applies to many of the wall paintings in the Mogao Caves. The pictorial renderings of the various perils from which Avalokiteśvara saves the faithful can be traced back to the Pumen pin 普門品 [Pumen Chapter] of the Saddharmapundarika (T. 262.9, 56c-58c), and as such are well-documented in paintings from the Tang period (618-907, 唐). Since that period, it became a sort of iconographical template for depictions of several Avalokiteśvara types in China. ${ }^{15}$ Certainly this is borne out in the Buddhist art of Dunhuang.

In the lower right side of the painting, within the frame of the primary icon, is an image of a kneeling youthful monk. He faces the deity and holds an incense burner in his hand. The cartouche next to the monk reads: "Wholeheartedly offered by the Great Master Yuanman of the Zhang clan [(張氏)]" (fig. 4.3). ${ }^{16}$

This is not only a donor portrait of a Buddhist cleric Yuanman (fl. second half of 1oth c., 圓滿); the portrait has been fully inserted into the painting of Ekādaśamukha, such as is common for donor portraits during the Tang. However in this case, the portrait of Yuanman is a relatively large size, which indicates a conceptual and artistic usurpation, almost akin to religious hubris. Perhaps Yuanman had already passed away when the painting was commissioned,

15 In Dunhuang this iconographic template occurs in various contexts, many of which are somewhat divorced from its origin in the Pumen Chapter. It is common to have these scenes of salvation together with Esoteric Buddhist images of Avalokiteśvara. Cf. e.g. OA 1919,0101,O.2, MG 17665, OA 1919,0101,0.36, etc.

16 Harvard Art Museum, 1943.57.14: 故圓滿大師姓張氏一心供養. 


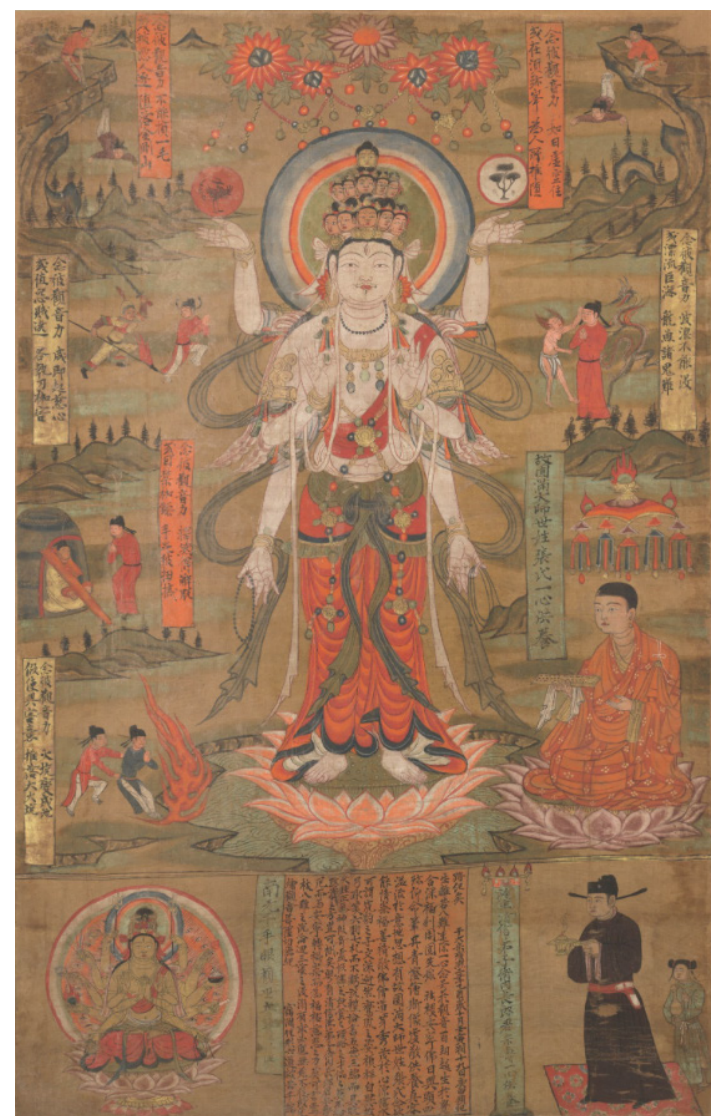

FIGURE 4.2

Ekādaśamukhāvalokiteśvara.

Dunhuang, dated 985 .

1943.57.14, HARVARD ART MUSEUM.

which may have justified his portrait being painted within the primary composition itself. ${ }^{17}$

At the bottom of the painting is the usual separate section reserved for donor portraits and dedications. There is a portrait of a person dressed in the robes of an official, also a common feature of paintings from Dunhuang. He is furnished with an identifying inscription in a cartouche, which reads: "Wholeheartedly offered by the principal donor, the pure-hearted disciple, official of the local government, the young gentleman and grandee, Zongshou."18

17 A similar case, namely the Tangut Emperor Renzong probably being depicted in the Ușnīṣavijayā depiction in Yulin Cave 3, is discussed in in this volume, "Creation of Tantric Sacred Spaces in Eastern Central Asia" by Carmen Meinert.

18 Harvard Art Museum, 1943.57.14: 施主清心弟子衛內張郎君宗壽一心供養. 


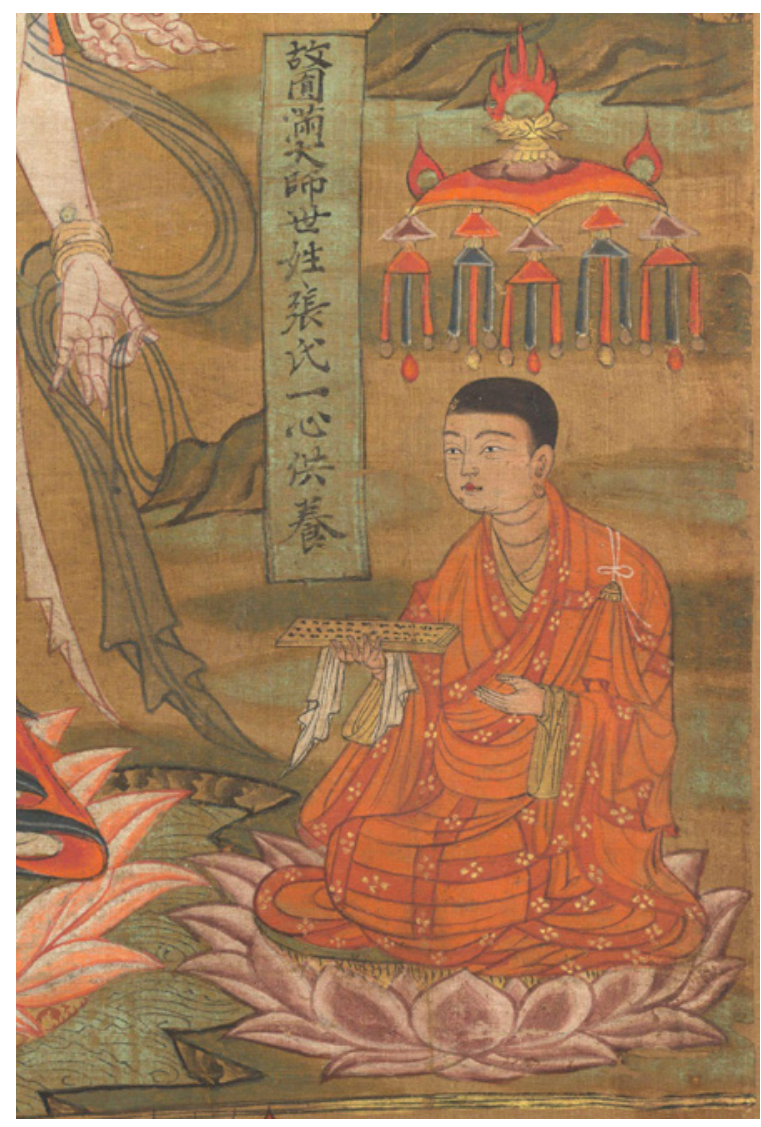

FIGURE 4.3

Detail of Ekādaśamukhāvalokiteśvara (figure 4.2)

The identity of the principal donor Zongshou (宗壽), is not entirely clear from the inscriptions of the painting. However, Cao Yijin (r. 914-935, 曹議金) had a great-grandson by this name. ${ }^{19}$ It is therefore logical that this important member of the Cao clan (曹氏) is identical with the donor in the painting. The temporal frame also fits, which means that in all likelihood Cao Zongshou (fl. late 1oth to early 11th c., 曹宗壽) is portrayed as the donor in this painting. His title shows that he was a lower-ranking official in the local government at the time of the donation.

On the opposite side of Cao Zongshou's portrait is the icon of the Thousandarmed Avalokiteśvara in seated form. It is also identified by a cartouche, the text of which is in the form of an invocation to the deity. The image represents

19 Cf. Ji Xianlin 季羡林 et al., eds., Dunhuang xue da cidian 敦煌學大辭典 [Dictionary of Dunhuang Studies] (Shanghai: Shanghai cishu chubanshe, 1998), 358-359. 
an iconographically standard rendering of this form of Avalokiteśvara, and as such is found in numerous examples of portable paintings and murals.

Further elucidation of the donation of the Ekādaśamukha painting is found in the lengthy record of the dedication of merit next to the portrait of Cao Zongshou. It reads:

Record of Merit [in connection with] a Silk Painting of the Bodhisattva Avalokiteśvara.

I have heard about his salvation of those in the Six Destinies, who are being pulled out of suffering the thousand extremities, and saved from drowning in the Eight Hardships, and those who repeatedly sink into the Three Mires. When there is someone who seeks help, there surely will be a response, but without prayers, there will be no compliance [unless] one corrects oneself. When in situations of danger, one will be granted peace and serenity; revolving in misfortune caused by evil influences may then be turned into blessings. [Indeed], the power of compassion cannot be spoken by words. The ways of the compassionate deliverance through compassion, how can it be estimated? It so happens that there is the Buddhist disciple, pure in faith, an official of the local government, the young gentleman and grandee [named] Zongshou. The true breath of heaven has divinely bestowed upon him unusual numinousity, an immense and extraordinary countenance and dignity. He is honest and astute, and gifted with [both] fervour and assurance. [...] He is able to speak about the Liji 禮記 [Book of Rites], the Lunyü 論語 [Confucius' Discourses], the Shujing 書經 [Book of History], the Five [Confucian] Virtues (Chin.wude 五德), and the Three Upright Things (Chin. sanduan 三端), and is moreover able to clarify them. He may [truly] be called a tiger or leopard cub; his cultured character reverts to spontaneity [endowed with] the appearance of a male phoenix, extraordinarily lucky and auspicious. Hence, he is able to show affection and esteem blessings of goodness, the essence of which is to respect the Buddha and the monks, so that the sprouts of the Way will manifest lushly in his mind's source. Watered by faith, it overflows the ground of thought.

Suddenly he remembered that there was the Great Master Yuanman, whose worldly family name was Zhang, a person he greatly admired, and [consequently] ordered brushes colours, and gauze [silk] on which to have this image painted and be presented as an offering. Its true appearance combined with variegated colours, the merit of which will benefit all. First, he prays that the gods of the land (Chin. sheji 社稷) will be at peace, that Buddhism [(lit. Buddha)] on a daily basis will flourish and 
become manifest, that all sentient beings may be apart from sufferings, and that the Eight Hardships will quickly be done away with. He wholeheartedly intones the name of Avalokiteśvara, so that he, for more than one hundred kalpas of rebirths, will be set on the road to awakening.

Recorded on the 19th gengshen day in the 1oth renyin lunar month in the 2nd yiyou year of the Yongxi [reign period] of the Great Song [i.e. $985] \cdot{ }^{20}$

Although most of the text of this inscription is couched in formal and hyperbolic language of the same kind as in the preceding example, it is nevertheless possible to distill a bit of useful data from it. First of all, it is immediately evident that there is no trace of filial piety here, no prayers for the well-being of parents and ancestors, and incidentally also no mention of rebirth in Amitābha's paradise. Therefore this dedication is, in its entirety, an expression of Buddhist piety and devotion to Avalokiteśvara in particular. Although it is not entirely clear, It is possible that Yuanman was a co-donor of the painting, although it is not entirely clear, while it is certain that Zongshou was the one who financed it.

The text of the dedication does not yield much to inform us of Zongshou's practice of Buddhism, except that he was a devotee of Avalokiteśvara. However, the manner in which it stresses his learning of the various Confucian classics is noteworthy. It not only casts him as a paragon of Buddhist virtue and piety, but also as a bearer of traditional Chinese culture, a true gentleman.

As a way of rounding off our discussion of this painting from the Harvard Museum Collection, the icon may document a de facto double cultic practice for worshipping two of the primary forms of Avalokiteśvara in accordance with the Esoteric Buddhist tradition. While such double or even triple formats can be found among the paintings from Dunhuang, they normally display devotion to different and often conceptually unrelated deities. However, in this case we see two major and important Esoteric Buddhist forms of Avalokiteśvara within the same icon. As such it underscores the considerable popularity and

20 Harvard Art Museum, 1943·57.14: 繪觀音菩薩功德紀 䊉聞化形六道, 拔苦千端, 拔八 難之沉淪, 回三途之沒溺, 有求必應, 無願不從, 改危厄而與安寧, 轉禍崇而爲福 佑. 慈悲之力, 莫可言焉. 烣濟之方, 豈可測矣. 粵有清信佛弟子, 衙內長, 郎君宗 壽, 天中正氣, 神假奇靈, 恢偉之貌堂堂, 樸略之才㑆㑆. 莫不拾弓取滿, 六鈞七札 而不虧. 說禮論書, 五德三端而具曉. 可謂虎豹之子, 文采迥然, 鸞鳳之姿, 禎祥自 異. 故能情崇福善, 精敬佛僧, 道芽秀茂於心源, 信水溢流於意地. 忽想有故圓滿 大師, 世姓張氏, 合世彌仰, 命筆丹青, 愳繪斯像, 發敬供養. 真容合彩, 福利周圓. 先願社稷安寧, 佛日興顯, 眾生離苦, 八難速除. 一心念號於觀音, 百劫超生於覺 路. 紀矣. 於大宋雍熙二年乙西歲十月壬寅朔十九日庚申題紀. 
importance which Esoteric Buddhist cults enjoyed among the common Buddhists in Shazhou towards the end of the reign of the Guiyijun.

The most common form of Amoghapāsaāvalokiteśvara found at Dunhuang -in both banner and wall paintings - is the seated, six-armed form. Incidentally, this form is also common among Amoghapāśa representations found elsewhere in China and East Asia from the 9th-1oth centuries. ${ }^{21}$

There are relatively few paintings in Dunhuang where this form of Avalokiteśvara is depicted alone, i.e. as a single icon. Usually he appears in the center of a mandala, in accordance with the ritual cycle of the primary sütra(s) dedicated to his cult, i.e. the various recensions of the Amoghapāśakalparāja (T. 1093.20, T. 1094.20, T. 1095.20, T. 1096.20, T. 1092.20, etc.), ${ }^{22}$ most of which were translated between the late 6th century and the very beginning of the 8th century. ${ }^{23}$

From the perspective of Esoteric Buddhism, one of the finest and most impressive of the Dunhuang paintings depicts the mandala of Amoghapāśa as the main icon with a secondary mandala representing the Vajradhātu (MG 3579 , fig. 4.4) ${ }^{24}$ As a painting featuring two mandalas, it is both a unique and intriguing icon, and although this specific painting has been discussed many times, none of these efforts have been particularly helpful in unraveling a number of central questions relating to it. ${ }^{25}$ I try to amend this situation by placing it under new scrutiny, with special attention placed on the donor figures.

One of the problems regarding this painting, in particular its pair of highclass donors, is the fact that neither were their names nor the central text of

$21 \quad$ For these developments, see Dorothy Wong, "The Case of Amoghapāśa," Journal of Inner Asian Art and Archaeology 2 (2007): 151-158.

22 The last of these represents the impossibly voluminous thirty fascicle version attributed to Bodhiruchi (fl. late 7 th to early 8th century).

23 For scholarly work on the Amoghapāśakalparäja, see the classical study by Meisezahl, R[ichard] O[tto], "Amoghapāśahṛdaya-dhāraniī: The Early Sanskrit Manuscript in the Reiunji. Critically Edited and Translated," Monumenta Nipponica 17-18 (1962-1963): 265-328; Maria Reis-Habito, "Amoghapaśa Sūtra: A Historical and Analytical Study," Studies in Central and East Asian Religions 11 (1999): 39-67.

24 It is briefly discussed in Sørensen, "Typology and Iconography," 206-308.

25 Cf. e.g. Robert Jera-Bezard and Monique Maillard, "Le rôle des bannières et des peintures mobiles dans les rituels du bouddhisme d'Asie centrale," Arts asiatiques 44 (1989): 57-67 (esp. 64-66). Many years ago, I did an initial survey of the painting. Cf. Sørensen, "Typology and Iconography," 306-308. 
dedication was added to the painting, which has made it difficult to identify them. Unfortunately, I cannot claim to solve this issue here, given the same limitations imposed on me as on those who previously worked with the painting. However, we will at least get a bit closer to such an understanding. Before attempting this, let us briefly review the format and lay-out of the painting first.

The top section of the painting features a basic mandala depicting the Five Dhyani Buddhas flanked on either side by two Esoteric Buddhist forms of Avalokiteśvara, namely Cintāmanicakra (on the left) and the Thousand-armed Avalokiteśvara (on the right). As such the composition is not iconographically orthodox, at least not compared to formal Esoteric Buddhist iconography and its textual backdrop. Rather it reflects the creative interpretation of local artists. However, the basic iconic template of the Five Dhyani Buddhas depicted here is found in wall paintings elsewhere in both the Mogao Caves and at Yulin (榆林). ${ }^{26}$ The Five Dhyani Buddhas all wear Five Buddha Crowns, and each of them holds the respective symbol of their family, i.e. vajra, lotus, jewel, etc. These iconographical features indicate that the group represents the central assembly of the Vajradhātu according to the Sarvatathāgata-tattvasamgrahatantra/Vajraśekharasūtra (T. 866.18, T. 865.18) and its several derivatives. ${ }^{27}$

The central mandala in the composition is devoted to the cult of Amoghapāśa. As in the examples discussed above, it shows the bodhisattva with the same attributes in his hands, but he wears, in addition to these, a Five Buddha Crown on his head, a feature which underscores the deity's relationship with mainstream Esoteric Buddhism. Its manner of iconographical composition rather closely follows standard examples of Amoghapāśa mandalas from

26 Cf. Dunhuang wenwu yanjiu 敦煌文物㗏究, ed., Dunhuang Mogao ku 敦煌莫高窟 [Mogao Caves in Dunhuang], vol. 4 (Beijing: Wenwu chubanshe, 1987), pl. 169; and Yulin $k u$ 榆林窟 [The Yulin Grottoes], ed., Dunhuang yanjiuyuan 敦煌矿究院, (Nanjing: Jiangsu meishu chubanshe, 2014), 47-48, pls. 10-11. Here the painting is wrongly dated to the mid-Tang. It is of course from the Later Tang.

27 This is represented by an entire cycle of texts belonging to what may originally have been a more coherent inter-connected set of scriptures, which still exist in the Chinese canonical (and extra-canonical) material as we have it today. In Dunhuang much of this material can be found in the form of textual digests or re-compilations, such as the celebrated Tanfa yize 壇法儀則 [Altar Methods for Ritual Proceedings (abbreviated title)] (P. 3913 , Beijing $1388 \mathrm{~V}^{\circ}$, S. $2316 \mathrm{~V}^{\circ}$, etc.). For a recently edited version of this comprehensive ritual compendium, see Fang Guangchang 方廣錩, ed., Zangwai fojiao wenxian 藏外佛教文獻 [Buddhist Texts Outside the Canon], vol. 11 (Beijing: Zhongguo renmin daxue chubanshe, 2008), 17-231. It is very briefly discussed in Henrik H. Sørensen, "Esoteric Buddhism at the Crossroads: Religious Dynamics at Dunhuang, 9th-1oth Centuries," in Transfer of Buddhism Across Central Asian Networks ( 7 th to 13th Centuries), ed. Carmen Meinert (Leiden, Boston: Brill, 2016), 250-284. 


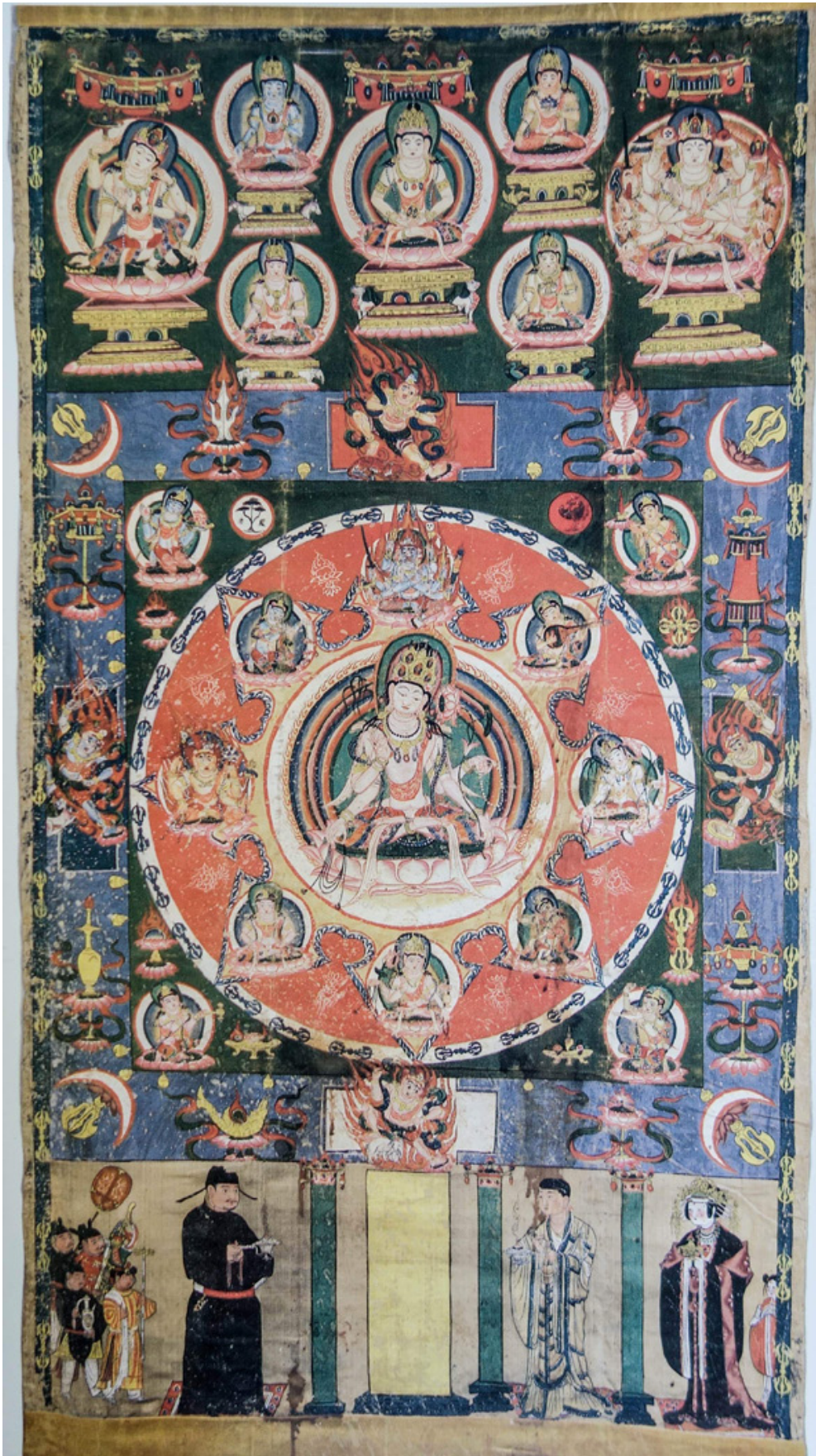

FIGURE 4.4 Amoghapāśa maṇdala. Dunhuang, second half of the 1oth c. MG 3579 
Dunhuang and elsewhere in East Asia, especially from the Japanese Heian period (794-1185, 平安時代). The present example is not exactly identical, but is comparable over-all and in general terms. The other deities surrounding the central image of Amoghapāśa are all emanations of Avalokiteśvara and include Hayagrīva, Tārā, Bhrūutuțī, etc. (T. 1096.20, 410c). The outer frame of the mandala features half-vajras resting on crescent shapes with lotus bases. The Four Offering Bodhisattvas representing the senses of vision, smell, taste, and hearing are in the four corners outside of the central part. In front of each of them are offerings on a small raised tray, and larger symbols below and above them indicate to which Buddha Family (Skt. kula) each belongs. Interspersed between the vajras are the Eight Auspicious Symbols (Skt. aștamangala) of Buddhism. Four wrathful guardian spirits block each of the gates in the four cardinal directions.

The third and bottom section of the painting consists of a pair of donor portraits, and is divided in the fashion typical of the Dunhuang paintings, with males and females on either side of a central frame meant to hold the text of the dedication. It is unusual that these were painted in gold, a feature usually only reserved for paintings of the highest artistic level.

Beginning with the left-hand side, we find the male donor dressed in a long official robe of dark color, wearing the corresponding hat with long wings. His face has a youthful expression, and in his right hand he holds an incense brasier with a long handle. Four attendants in military garb crowd behind, representing the carriers of the official insignia of the primary donor. They variously hold the regalia of a ruler, such as a staff of authority, an ewer, a pole fan, and weaponry. ${ }^{28}$

On the right-hand side of the composition are two figures rendered in equal size. The one closest to the central frame is a Buddhist cleric, most likely a nun in full robes. She holds an incense burner in the left hand and what appears to be a flower in the right hand. She wears a Buddhist rosary (Skt. $m \bar{a} l \bar{a}$ ) around her neck. Next to the nun is a portrait of what is likely the male donor's spouse. She is dressed in a robe indicating superior quality, but otherwise wears the same type of dress common to most female donors in paintings from the 1oth century. She wears an elaborate hairdo, essentially an over-decorated crown complete with heavy, radiating hairpins, jewel tassels, and most importantly a phoenix in the crest. Slightly behind her stands a young female attendant, depicted as if to peep out from behind a division.

28 For similar renderings of military attendants, see the portrait of Cao Yijin in Mogao Cave 16 at Yulin. Cf. Yulin ku, 78, pl. 45 . 
On stylistic grounds, there are several indications that MG 3579 and the Harvard Ekādaśamukha painting discussed above were painted by the same painter during roughly the same period. This view is supported by the manner in which the donor monks in both paintings are rendered and various other stylistic features. Since the text of the dedication and two donor colophons was not written, the identity of all three donors remains unknown. However, given the manner in which the attendants of the main male-donor are rendered, it appears we are dealing with a portrait of one of the Cao rulers and his wife, assisted by what is probably a nun.

One important iconographical feature evident in connection with these donors is the particular cartouches in green that emulate dhäranī-pillars. This manner of rendering cartouches for names in donor portraits from Dunhuang is normally reserved for images of the Guiyijun rulers. In any case, it is not found with the usual donor portraits of lower-ranking people. While these pillar-like cartouches are fairly rare in votive paintings, they are seen with some regularity in donor portraits in wall paintings. This feature is found in connection with portraiture from the early Cao reign onwards, in particular in paintings representing Cao Yijin, such as those in Mogao Cave 100 (fig. 4.5).

The same feature may be observed in Cave 16 at Yulin, where a similar group of attendants carry the ruler's official insignia in the adjacent portrait of Cao Yuande (r. 935-939, 曹元德) (fig. 4.6). Clearly this group of figures represents a formal iconographical norm for rendering attendants of royalty. ${ }^{29}$

Despite the perfunctory nature of the above observations, we are well on our way to solving the possible identity of at least the identities of two of the three donor figures portrayed in MG 3579. Given that the pillar-like cartouches are only found in connection with portraits of Cao rulers, i.e. from the period between 914 to around 1037/1038, and that our painting falls well within the first half of this time frame, we are now in the position to narrow down the possible candidates to four: namely Cao Yijin himself, Cao Yuande, Cao Yuanshen (r. 939-944, 曹元深), and Cao Yuanzhong (r. 944-974, 曹元忠). It is of course, not certain that the portrayed male is one of these four. He could also be one of their sons or a close relative of royal descent. ${ }^{30}$ However, I favour either

29 Slightly later examples from the Dali Kingdom in Yunnan reveal the same overall manner of rendering such attendants. Cf. Helmut Brinker, ed., Der Goldschatz der Drei Pagoden: Buddhistische Kunst des Nanzhao- und Dali-Königreichs in Yunnan, China (Zürich: Museum Rietberg, 1991), 42-43, pls. 16-17. In this connection it is also useful to compare traditional images of the Four Heavenly Kings, each of whom in some cases are provided with similar groups of attendants holding their insignias, banners, and other regalia.

30 See the Water-Moon Avalokiteśvara in the Freer Gallery (F1930.36) dated 968. In the catalogue text of the museum, the donor is referred to as Cao Yanqing (fl. second half of 1oth c., 曹延清), supposedly a son of Cao Yuanzhong. However, I am reluctant to accept such a view at face value. Mainly because it is not based on documented evidence 

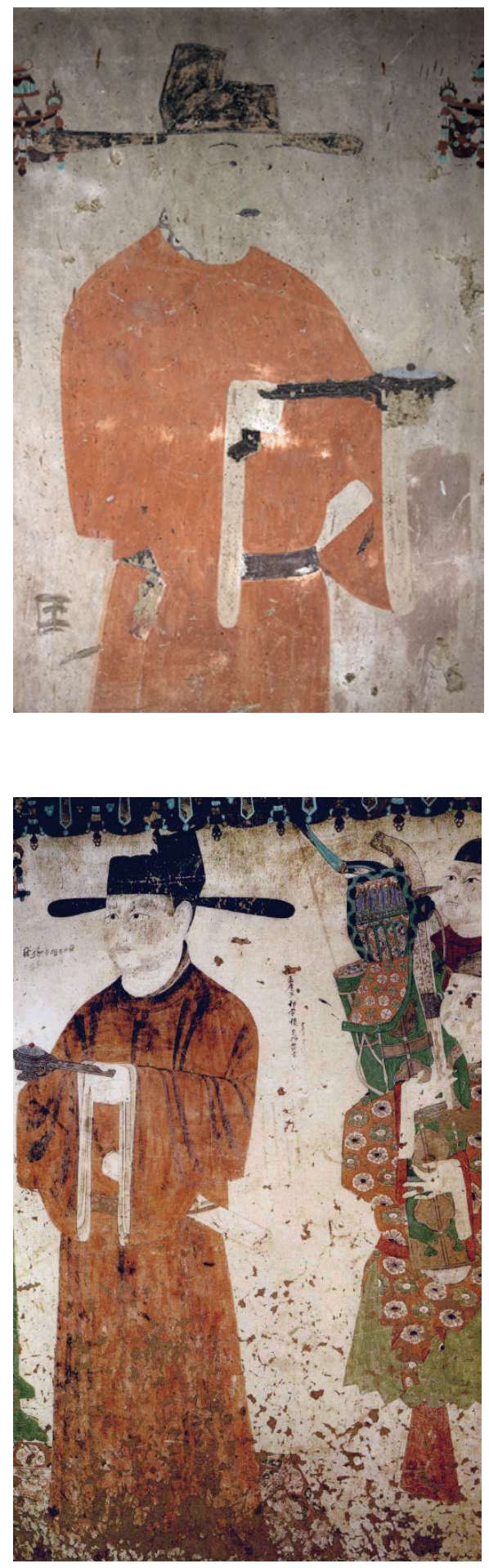

FIGURE 4.5

Donor portrait of Cao Yijin. Mogao Cave 10O, 1oth c.

(C) MOGAO GROTTOES, DUNHUANG, GANSU, CHINA
FIGURE 4.6

Donor portrait of Cao Yuande. Mogao Cave 100, 1oth c.

(C) MOgAo GROTtoes, DUNHUANG, GANSU, CHINA 
Cao Yijin or Cao Yuanzhong as the most likely candidate for our portrait, with the woman as the principal wife. Cao Yuanzhong was an extremely devout Buddhist, and his activities as a fervent patron are well-documented. Therefore it may be him represented here, as the physical likeness between our donor and that of Cao Yuanzhong found on the southern wall of the corridor of Cave 19 at Yulin is striking. However, given the fact that these donor images are in many cases idealised or stereotypical in nature, we can not place too much trust in such similarities. ${ }^{31}$

Among the scores of banner paintings from Mogao Cave 17, are some which represent alternative iconographical conceptions than the range of images that are based on more formal scriptures sources. Among these are MG 23079, ${ }^{32}$ which depicts a standing, six-armed Amoghapāśa with the usual donor panel at the bottom (fig. 4.7). The painting itself is fairly large and is painted in ink and colours on a type of fine hemp cloth. According to Lilla Russel-Smith, the painting reflects Uyghur stylistic influence, which may or may not be correct. But it is abundantly clear that the donors depicted are all local Chinese, since they are clearly referred to as belonging to local clans. Moreover the males are evidently lower-ranking military officiers in the Guiyijun army. ${ }^{33}$

The example of Amoghapāśa in MG 23079 is iconographically unusual in that it is depicted in standing mode. Moreover, it is divorced entirely from its scriptural context, since all secondary images belonging to its ritual cycle are absent. Compared with other examples of Amoghapāśa from Dunhuang, e.g. MG 26466, MG 1131, and MG 23076, it is evident that MG 23079 represents an

deriving from primary sources, but from a copy of the name that was once visible on the painting, i.e. the piece of the name that is now lost. Cf. the description in the catalogue text accompanying F1930.36. In any case, and despite the fact that everybody seems to believe this identification blindly and has moreover replicated it endlessly, I consider it a mistake. Mainly because there are virtually no other primary sources with which to verify this name. Perhaps the portrait was actually meant as a representation of Cao Yangong ( $\mathrm{r}$. 974-976, 曹延恭)? What is noteworthy, however, is that the portrayed scion of the Cao clan is also furnished with the same the pillar-like cartouche, which underscores that this was indeed a designator reserved for the royal clan of Dunhuang.

$31 \quad$ Cf. Yulin ku, 84, pl. 51 .

32 Jacques Giès, Les arts de l'Asie Centrale: La collection Pelliot du musée Guimet, 2 vols. (Tokyo and Paris: Kodansha Ltd. and Reunion des Musees Nationaux, 1994), pl. 79.

33 Lilla Russell-Smith, Uygur Patronage in Dunhuang Regional Art Centres on the Northern Silk Road in the Tenth and Eleventh Centuries (Leiden: Brill, 2005), 124 and 236. 
artistically inferior and possibly also cheaper work. As such it belongs together with the relatively large group of banner paintings produced by less skilled painters for mid-level officials and clans in Dunhuang's social hierarchy.

The dedication of the donation in the central part of the lower register dividing the donors reads:

The disciple of pure faith, Deng Xingquan, has had this one image of the Bodhisattva Amoghapāśa made. Firstly, on behalf of the people of the kingdom $[\ldots],{ }^{34}$ so that they may be in peace. [Next] on behalf of his past departed parents, so that they may attain rebirth in the Pure Land. [He also] prays for a harmonious family without $[\ldots]^{35}$ being evident. This was eternally bestowed as an offering. Recorded on a day in the fourth month of a gengshu year [i.e. 950 or 1010]. ${ }^{36}$

Lastly the text of the individual cartouches reads: "[Whole-heartedly offered by] the deceased, compassionate father Deng Wenhuo. Whole-heartedly offered by the male Deng Xingquan." 37

The rather rudimentary dedication and the two identifying texts stating the names of the donors, i.e. Deng Xingquan (n.d., 鄧幸全) and his father, do not reveal much concerning their degree of Buddhist practice, nor little regarding their beliefs. However, the text does underscore the fact that many of these offerings of paintings were part of some form of ancestor worship, in so far as Mr. Deng had the portrait of his deceased father inserted as one of the principal donors (fig. 4.8).

The donor inscription features a number of the same concepts and cultural patterns seen in many of the other banner paintings from Dunhuang, including the central concern for deceased parents, the images of which together with their formal dedications of the pious work, actually made by their descendants on their behalf, incorporate them into the process of returning merit believed to derive from the creating of the banner painting. Although the icon here obviously belongs to a special Esoteric Buddhist belief system, in this case the cult of Amoghapassa and its related ritual practices, the dedication and prayers appended to the painting do not provide any additional information on this. Hence, one might surmise that a deeper engagement with Esoteric Buddhism, especially on the level of practice, was not a primary concern for

\footnotetext{
34 One character is illegible.

35 Two characters are illegible.

36 MG 23079: 清信弟子鄧幸全敬造伯空卷索菩薩 壹軀. 先奉爲國人安 $\square$ 一爲過往 父母, 秉生淨土, 願合家無 $\square \square$ 彰, 永充供養. 庚戌年四月日.

37 MG 23079: 故慈父鄧文或一心 [供養] 男鄧幸全一心供養.
} 




FIGURE 4.7

Amoghapāśa.

Dunhuang, dated

1010 .

MG 23079 .

the donors. In fact, the main icon might as well have been Kșitigarbha or some other major Buddhist deity, since an expression of piety and devotion is at the heart of the practice. Even so, the cult of Amoghapāśa was very popular at Dunhuang during the 9th-1oth centuries, as documented by the existence of several banner and wall paintings, all of which underscore the importance of Esoteric Buddhism at that time. 


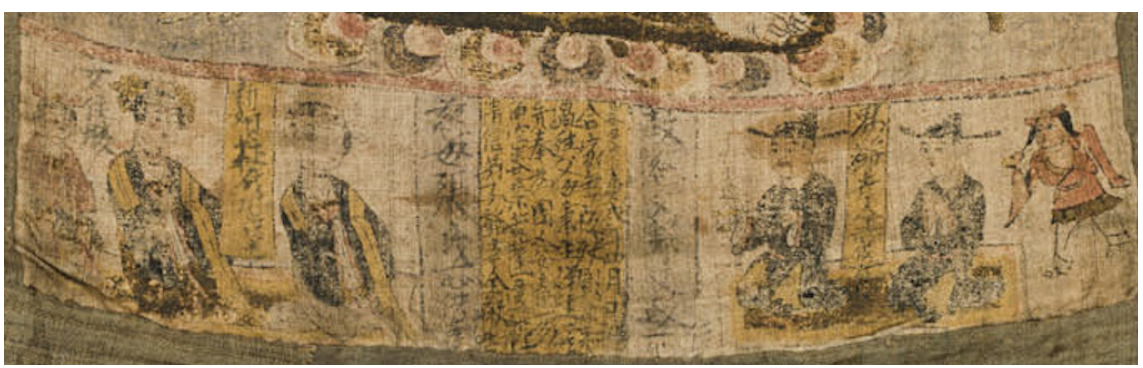

FIGURE 4.8 Detail of Amoghapāśa (figure 4.7)

Before concluding the discussion of this painting and its context, we should mention that the name Amoghapāśa is written as 'Bokongjuansuo pusa' (伯空 卷索菩薩), which—although it is somewhat unusual—is not so far removed as to constitute a simple error. Rather, it is a case of a different manner of transcription for the bodhisattva's name, a phenomenon commonly encountered among the Dunhuang manuscripts (and elsewhere). ${ }^{38}$

Among the lesser-noticed votive paintings from Dunhuang is one featuring the Bodhisattva Kșitigarbha, now in the Freer Gallery of Art (fig. 4.9) ${ }^{39}$ Like some of the other paintings discussed here, this one also features a tripartite division with a main image and two secondary fields with images below, one depicting the donor and the other an additional divinity.

Obviously Kșitigarbha is not a deity specifically associated with Esoteric Buddhism or its pantheon, but rather is an 'all-round' bodhisattva saviour, the cult of which had broad appeal for people from all walks of life in traditional Chinese society. ${ }^{40}$ However, the present painting has an additional feature in

38 Imre Galambos has briefly discussed the donor inscription of MG 23079 in a recent article, but in my view he makes too much out of the manner in which the name of Amoghapāśa has been transcribed. While not exactly 'orthodox' it is also not indicative of a lack in understanding on the part of the donor(s) as he claims. Cf. Imre Galambos, "Non-Chinese Influences in Medieval Chinese Manuscript Culture," in Frontiers and Boundaries: Encounters on China's Margins, ed. Zsombor Rajkai and Ildikó Bellér-Hann (Wiesbaden: Harrassowitz, 2012), 71-86 (esp. 79).

39 Freer Gallery F1935.11. The painting is said to have entered the museum's collection in 1935 .

40 See Ng Zhiru, The Making of a Savior Bodhisattva: Dizang in Medieval China (Honolulu: University of Hawai'i Press, 2007). For a more specific study of this bodhisattva in 
the form of an extra icon, namely that of Vajrasattva, one of the primary Esoteric Buddhist and Tantric deities.

The main image of Kșitigarbha depicts the bodhisattva seated in a somewhat unusual setting. He is only attended by a military figure on his left, who represents one of the Ten Kings of the Netherworld (Chin. shidian yanluo, 十殿閻羅), i.e. Wudao Jiangjun (五道將軍), depicted in full armour and holding the bodhisattva's staff (Skt. khakkhara). To Kșitigarbha's right is a small image of a crouching monk, probably meant to be Daoming (道明), a character from the Kșitigarbhasūtra, together with a small reclining lion. The entire setting has an almost elegant, tropical ambience, which is slightly unusual in the context of the Buddhist iconography from Dunhuang. As Dunhuang paintings with the Kșitigarbha-theme (with or without the Ten Kings of the Netherworld) have been studied in great detail by several scholars in the past, there is no need to repeat what has already been said on this topic. ${ }^{41}$ It will suffice to say that the Freer painting's overall iconographical conceptualisation is somewhat off, if not downright peculiar. This is because the cult of Kșitigarbha rarely if ever appears in an Esoteric Buddhist context, at least in late medieval China, as is the case here. Below I try to account for this anomaly. Bypassing the main image of Kșitigarbha, we are free to discuss the two other images in the painting, starting with the female donor in the lower right side.

At the bottom of the painting on the right side is a donor portrait depicting a richly dressed, noble lady, seated with a votive offering of a lotus flower in her right hand. In addition to her bright red robe and ornate hairdo, replete with golden pins and other decorations, she wears a fancy phoenix tiara similar to the donor portrait of the wife of the Khotanese king in Mogao Cave $98 .^{42}$ The two small figures of her attendants hold royal regalia similar to those accompanying the Guiyijun rulers above. Although the central cartouche was meant to hold the formal text of the painting dedication, a short caption next to the image of the female donor provides a clue of who she is. The caption reads:

Dunhuang, see Wang-Toutain, Françoise, Le Bodhisattva Kșitigarbha en Chine du ve au XIIIe Siécle (Paris: Presses du L'École française d'Extrême-Orient, 1998).

See Stephen F. Teiser, The Scripture on the Ten Kings and the Making of Purgatory in Medieval Chinese Buddhism (Honolulu: University of Hawai'i Press and Kuroda Institute, 1994). See Wang-Toutain, Le Bodhisattva Ksitigarbha; and Henrik H. Sørensen, "The Meeting of Daoist and Buddhist Spatial Imagination: The Construction of the Netherworld in Medieval China," in Locating Religions: Contact, Diversity and Translocality, ed. Reinhold F. Glei and Nicholas Jaspert (Leiden, Boston: Brill, 2017), 234-292.

42 Cf. Dunhuang Mogao ku, vol. 5, pl. 13. For a similar headdress worn by royal Uyghur donors (Ganzhou Uyghurs), cf. ibid., pls. 177, 79. 


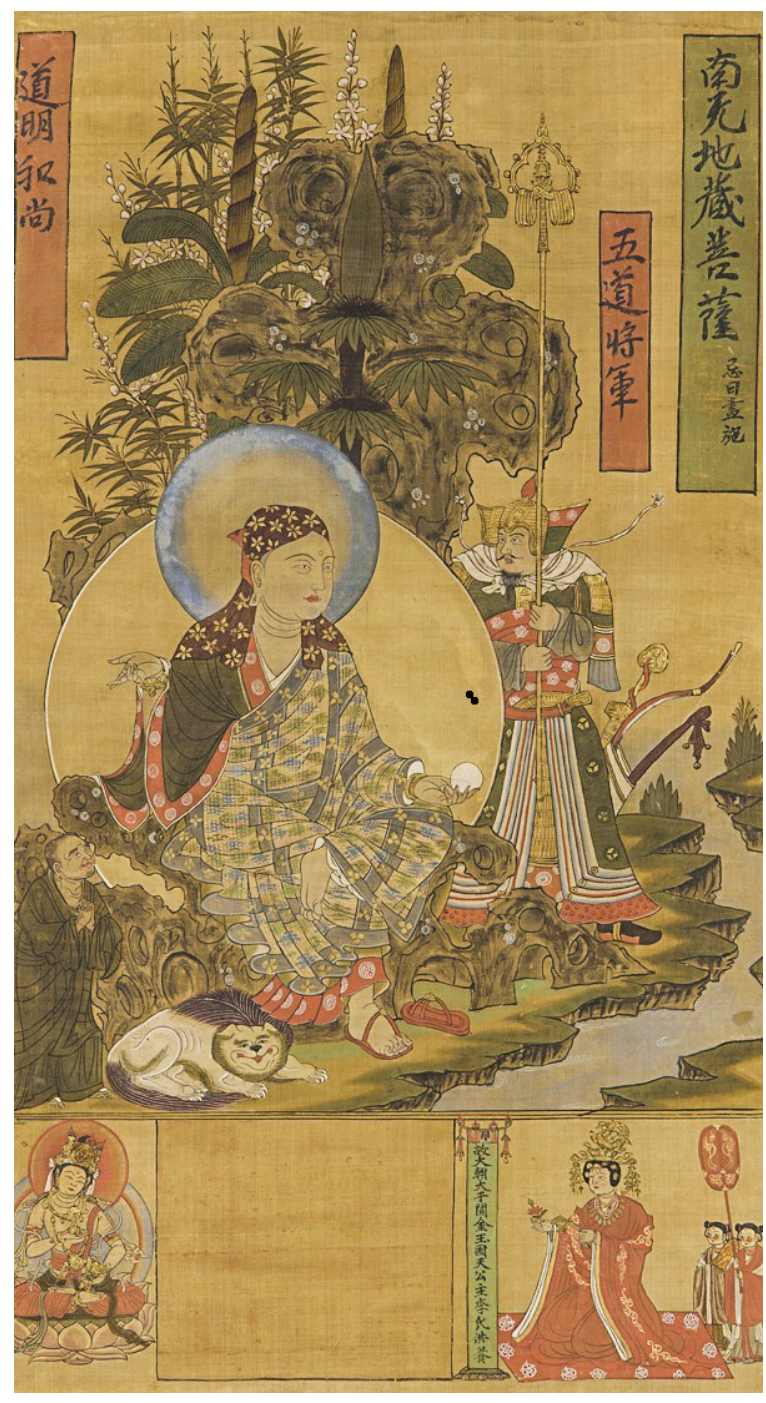

FIGURE 4.9

Kṣitigarbha with Vajrasattva as secondary image.

Dunhuang, second half of 1oth c.

F1935.11, FREER GALLERY

In commemoration of the deceased Heavenly Lord, Sovereign of the Great Court of the Great Khotanese Gold and Jade Kingdom, bestowed as an offering by the [wife of] the Li Family. ${ }^{43}$

Again we see here a double-painting, i.e. a painting featuring two primary images as its primary icons, actually a tripartite painting, with the Bodhisattva

43 F1935.11: 故大朝大于闐金玉國天公主李氏供養. Li (李) is the Chinese family name formally given to the rulers of the Khotanese royal house. 
Kșitigarbha as the primary image, appropriately so since we are dealing with a votive painting dedicated to a deceased person of high rank. The bottom part is divided into two scenes, the right side with the lady donor and the left side with an image of the Bodhisattva Vajrasattva holding vajra and ghanța, a primary deity of mature Esoteric and Tantric Buddhism. The manner in which the female donor sits facing Vajrasattva seems to indicate that she has a special bond with this divinity, who might be interpreted as her deity of initiation or her meditational deity (Tib. yid dam). In formal Esoteric Buddhism, there is no overt connection between Kșitigarbha and Vajrasattva, each of whom have their own separate and quite distinct cults, similar to the above case concerning Kșitigarbha and the Thousand-eyed Avalokiteśvara. Therefore the Freer painting is yet another example of the collapse of two purposes into one, i.e. possibly the donor wished to address two concerns in the same painting, namely an overt petition to Kșitigarbha as Lord of the Netherworld on behalf of the deceased Khotanese royal husband, and an invocation to Vajrasattva, who in this case may be seen as a reflection of a personalised expression of devotion on the part of the donor herself.

When trying to identify the donor portrait in this painting, the only possible person to fit with our female donor, obviously a woman of high nobility pedigree, is the daughter of Cao Yijin, who was married to Viśa' Sambhava, also known as Li Shengtian (r. 912-967, 李聖天), the king of Khotan. She is known in various documents as the Heavenly Consort (Chin. 天皇后) (P. 4516V', P. $\left.4518 \mathrm{~V}^{\circ}(2)\right) .{ }^{44}$ If this assessment is correct, the painting was done shortly after Viśa' Sambhava's death, say around 967, during the early Northern Song (96o-1126, 北宋).

Given that the painting was made by a member of the Khotanese royal family and that it features Vajrasattva as a major divinity in addition to Kṣitigarbha, we must surmise that Esoteric Buddhism played some role-or at the very

44 Portraits of the Khotanese royal couple in question can be found among the donors painted on the walls of Mogao Caves 61 and 98. For their names among the donors of Cave 61, see Dunhuang Mogao ku gongyang ren tiji [Donor Inscriptions from the Mogao Caves in Dunhuang; hereafter DMGT], comp. Dunhuang yanjiu yuan 敦煌㸴究院 (Beijing: Wenwu chubanshe, 1986), 21, and in Cave 98, ibid., 32. The later cave was inaugurated in 925 during the reign of Cao Yijin and later repaired by his successors. Cf. Zhongguo bihua quanji:Dunhuang 9 (Wudai-Song) 中國壁畫全集: 敦煌 9 (五代一宋) [Complete Collection of Chinese Wall Paintings: Dunhuang 9 (Five Dynasties-Song)], comp. Zhongguo bihua quanji bianji weiyun hui 中國壁畫全集編輯委員會 (Shenyang: Liaoning meishu chubanshe, 1990), pls. 4-5. For the relevant inscriptions, see DMGT, 32. One will note that the female donor of the Freer painting and the royal spouse represented in the wall painting wear similar clothing and ornaments, the only major difference being the colours of their respective robes. 
least enjoyed a certain presence-in the kingdom of Khotan during the second half of the 1oth century.

\section{$8 \quad$ Kṣitigarbha and Ekādaśamukha as Dual Icons}

Among the other votive paintings from Dunhuang providing evidence for the conflation of two otherwise distinct Buddhist cults, we have the example of MG 3644 , a painting that despite being published several times, has so far largely failed to have its more intricate secrets unlocked. The theme of this painting is again the Bodhisattva Kșitigarbha presiding over the tableaux of the Ten Kings of the Netherworld, and as such the iconographical format does not deviate much from a series of other paintings from Dunhuang with the same theme. ${ }^{45}$ What is noteworthy in this case is that the figure of Kșitigarbha as the main icon in the painting has been augmented with an additional primary image, namely that of Ekādaśamukha, the Eleven-headed Avalokiteśvara, who is depicted next to him, both figures set under a pair of elaborate umbrellas (fig. 4.10).

The bottom panel is made up of the usual donor portraits, in this case three adult figures on each side and a young boy and girl at each end, with males and females duly placed on either side of the central, empty cartouche. Evidently the donor dedication and most of the cartouches bearing the names of the donors were never filled in, with only a few of the other cartouches completed text. Given that the painting represents a fairly high-quality work in comparative terms, combined with the fact that gold was used in several instances for the cartouches, we must surmise that this icon was made by members of a leading clan in Dunhuang, again possibly at the request of a member of the ruling Cao. One indication of this is the small figure of the girl on the far left, who wears a fancy red dress and the same elaborate head gear as the three female donors. These surely indicate high-level status similar to the image of the female donor in the Kșitigarbha from the Freer Gallery discussed above.

With the possible exception that among the stone sculptures of Sichuan (四川) we sometimes find isolated examples of Kșitigarbha and Avalokiteśvara within the same niche, indicating that the pair of saviours do have a conceptual pre-history in the earlier Tang material, ${ }^{46}$ we have no documented or cul-

45 Cf. e.g. OA 1919,0101,0.23, OA 1919,0101,o.19, etc.

46 For one such example cf. e.g. group no. 16 at Qianfoyan (千佛岩) in Jiajiang (夾江). It is discussed in Henrik H. Sørensen, "The Sculptures at the Thousand Buddhas Cliff in Jiajiang, Sichuan Province," Oriental Arts (1997): 37-48. See also Yu Chun 于春 and Wang Ting 王婷, Jiajiang Qianfoyan: Sichuan Jiajiang Qianfoyan gudai moya zaoxiang kaogu 


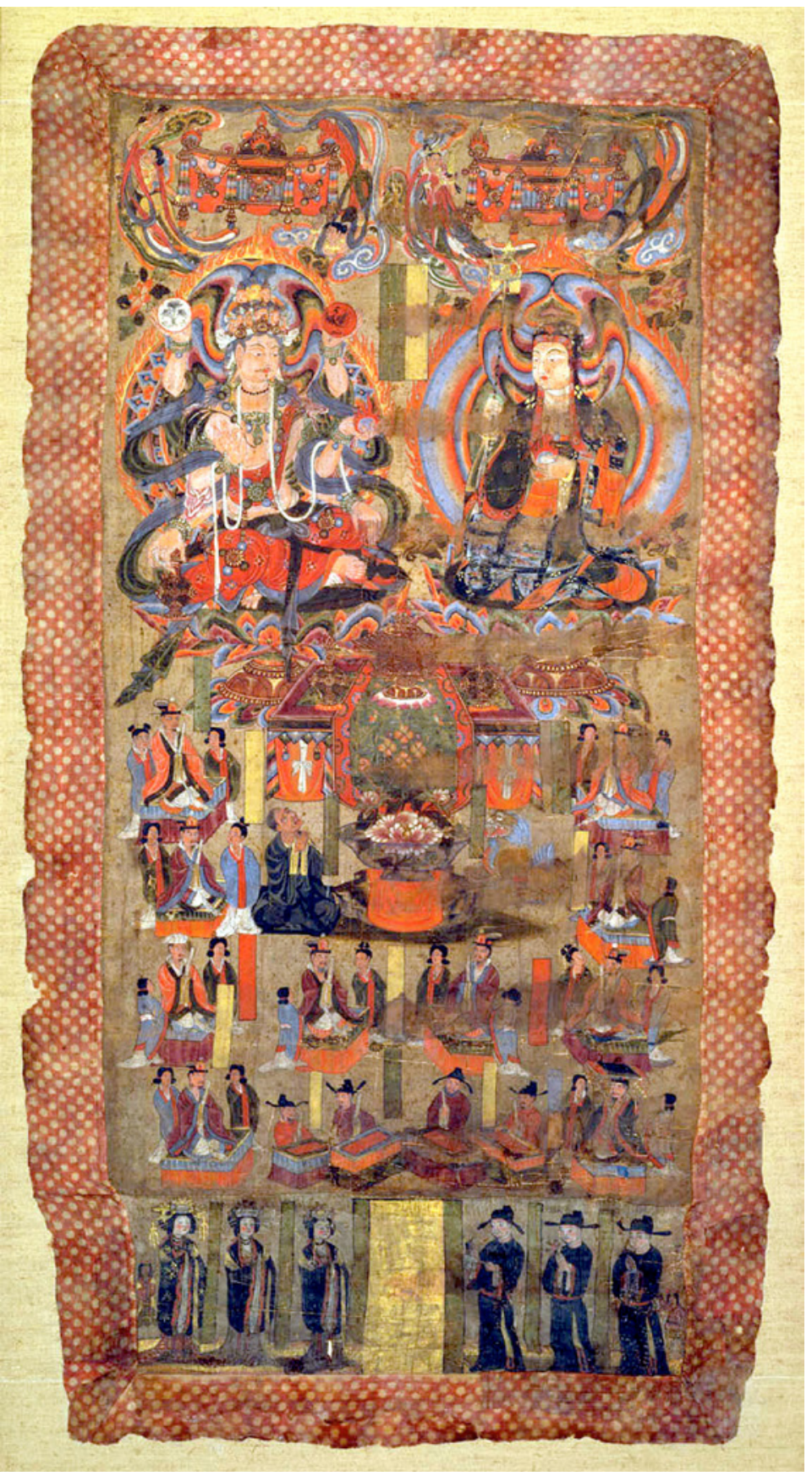

FIGURE 4.10 Dual image of Kṣitigarbha and Ekādaśamukha. Dunhuang, 1oth c. MG 3644 
tic precedents of the presence of this pair of primary bodhisattvas elsewhere in the material from Dunhuang. As was probably also the case for the Sichuanese examples just mentioned, it seems logical enough to have an icon produced which features the two primary saviour-bodhisattvas par excellence within the same picture frame. One could therefore see this iconic doubling as representing something akin to a full guarantee for salvation.

Ekādaśamukha is a major figure in the Esoteric Buddhist pantheon, and in fact has a relatively frequent presence among the images and tableaux of the wall and votive paintings of Dunhuang. His inclusion into what is otherwise a primary tableau of Kșitigarbha and the Ten Kings raises two ways to interpret this fascinating but curious painting. I propose that in the case of MG 3644 , we are dealing with something slightly different than we have seen previously in cases where two (or even three) iconographical themes are placed within the same picture frame, but reflecting a graded or hierarchical priority. In this case, the two otherwise distinct bodhisattvas are present within the same composition and seemingly of equal iconic importance. In other words, they were meant to be worshipped as an ensemble. The major part of the painting is taken up by the judicial courts of the Ten Kings, which leaves us in little doubt that this was meant as an offering in connection with a funerary event-possibly a seven-seven-type of ceremony (Chin. qiqi zhai 七七齋). ${ }^{47}$ It appears that somehow the cult of Ekādaśamukha has been grafted onto that of Kșitigarbha. After all, the Ekādaśamukhadhāranīsūtra promises salvation from rebirths in the Three Evil Destinies (Chin. sanmie 三滅) through the use of its spell and ritual proceedings. ${ }^{48}$ The other explanation, perhaps less colourful, is that since both bodhisattvas are important saviours in their own right, what we have here may just be a case of double devotion, similar to the earlier examples in stone from Sichuan, and therefore we should not place too much importance on Ekādaśamukha's role as a major Esoteric Buddhist divinity.

diaocha baogao 夾江千佛岩: 四川夾江千佛岩古代摩崖造像考古调查報告 [The Thousand Buddha Cliff at Jiajiang: A Report of the Archaeological Investigation of the Ancient Cliff-carved Sculptures at Qianfoyan at Jiajiang in Sichuan] (Beijing Wenwu chubanshe, 2012), 55-57, pl. 28. Unfortunately this voluminous resource offers no attempt at identifying the group. For an example that is closer in time to our example from Dunhuang, and which also features the Ten Kings, see Tom Suchan, "The Eternally Flourishing Stronghold: An Iconographic Study of the Buddhist Sculpture of the Fowan and Related Sites at Beishan, Dazu ca. 892-1155" (PhD diss., Ohio State University, 2003), 521524 .

47 For a discussion of this type of ritual in the context of Dunhuang under the rule of the Guiyijun, see Sørensen, "The Practice of Giving: Buddhist Donors and Donor Dedications from 1oth Century Dunhuang," BuddhistRoad Paper 4.3 (2019).

48 I.e. as someone reborn in hell, as a preta, or as a domestic animal. 
Overall, based on the material presented here, I conclude that Esoteric Buddhism and associated forms of belief held a significant position among the Buddhists in the Dunhuang area throughout the 1oth century, even though it was surely not the only important form of Buddhism there. The relationship between Esoteric Buddhism and the local Buddhist population in general is hard to gauge with any degree of certainty on the basis of these paintings alone, but it is clear that it was popular among the upper classes, given that a good number of the donated votive paintings, especially those reflecting a high quality of artistic execution, were directly related to it.

Since votive paintings are usually_or at least commonly-meant for display in ritual settings, we may surmise that the Esoteric Buddhist paintings, or those reflecting its iconography, were used in the performance of specific rituals. This means that worship of the Five Dhyani Buddhas, especially as expressed in the ritual cycle of the Sarvatathägatatattvasamgraha, the various Esoteric Buddhist forms of Avalokiteśvara, Vajrasattva, Sitātapatrā, Marīcī, etc., took place in the temples of Shazhou with a certain frequency during the period in question. This underscores our assumption that the worship of these icons were, to a large extent, part of current beliefs. To a certain extent, this is also supported by the extant liturgical material found among the hoard of manuscripts, such as those prayer texts used in connection with certain ritual proceedings. Examples of this include the Jietan sanshi fayuan wen 結壇散食 發願文 [Prayer Text for Making an Altar for Distributing Food (Offerings)] (D. 8953.54), the scattered manuscripts of the important Tanfa yize 壇法儀則 [Ritual Rules for Altar Methods] ${ }^{49}$ (P. 3919, Beijing $1388 \mathrm{~V}^{\circ}$, S. $2316 \mathrm{~V}^{\circ}$, etc.), and other similar documents found among the Dunhuang manuscripts. In many cases this type of liturgical text features the invocation of many of the divinities inhabiting the Esoteric Buddhist pantheon, underscoring without any doubt the great importance of this tradition locally.

The relationship between image and text is of course one of the salient features of mature Esoteric Buddhism in China, as well as of the early

49 Abbreviated title. The full title is: Jingang junjing jingang ding yijie rulai shenmiao bimi jingang jie da sanmeiye xiuxing sishier zhong tanfa jing zuoyong wei tanfa yize - Da Piluzhena jingang xindifamen mi fajie tanfayize 金剛峻經金剛頂一切如來深妙秘密金剛 界大三昧耶修行四十二種壇法經作用威壇法儀則大毘盧那金剛心地法門秘法 戒壇法儀則 [The Lofty Vajra Scripture, Vajraoṣnịșa of All the Tathāgatas, the Deep and Wonderful, Secret Vajradhātu, Great Samaya, the Scripture for Cultivating the Forty-two Kinds of Methods [for Setting up] the Altar Employing the Awesome Methods of Ritual Proceedings, The Mahāvairocana Vajra Mind Ground Dharma Door, Esoteric Dharma Precepts Altar Methods of Ritual Proceedings]. 
Indo-Tibetan Tantric tradition that arose more or less simultaneously. The impact of both was felt in the region with increasing effect during the 1oth century. The many examples of the central presence of this material in Dunhuang, both as reflected in the votive paintings discussed above, and in the murals, document that Esoteric Buddhist imagery and the cults they represent were relatively widespread and popular during most of the 1oth century.

Is it fair to say that the donors of the Esoteric Buddhist paintings we discussed here saw themselves as followers of Esoteric Buddhism? Probably they did, but perhaps not exclusively so, as we know that at least some of them also expressed their Buddhist faith in the context of more mainstream cultic practices. Essentially Buddhism at Dunhuang during the reign of the Guiyijun was many-faceted and polyvalent, encompassing a wide range of Buddhist beliefs and practices. Therefore, we may conclude that while the various cults associated with Esoteric Buddhist deities were indeed quite popular locally, at least among the members of the higher echelons of society, they were worshipped alongside other, more common Buddhas and bodhisattvas. This situation is also reflected in the way the caves created during this time were decorated. None show a dominant Esoteric Buddhist iconography, but in many caves Esoteric Buddhist themes appear alongside more general forms, such as paradise scenes and generic Buddha assemblies.

Based on the examples given here, we are now in the position to say a few things about Buddhist donors at Dunhuang and their relationship with Esoteric Buddhist beliefs and practices. First of all, it is clear that the donor dedications accompanying some of these paintings do not inform us of deep-level comprehension or mastery of Esoteric Buddhism. Most of the textual data we have shows that the Esoteric Buddhist imagery, important as it might have been in the performance of rituals by specialists, is not treated by devotees very differently than more mainstream Buddhist icons. This is to say that Esoteric Buddhism was not just seen as just another aspect of Buddhism. The reason why Esoteric Buddhis imagery occurs so frequently as it does, is because Esoteric Buddhism itself was present in Dunhuang. It appears that formal display of Buddhist piety was the most important function and expression of worship by the ruling clans. Because there was a rich imagery representative of the Esoteric Buddhist pantheon to take from, pictorial representations related to it became common. In other words, Esoteric Buddhist iconography was employed because it was popular. The Buddhist clerics who officiated at most of the rituals performed by and for the members of the lay community in Dunhuang had a deep knowledge of Esoteric Buddhist lore, and most probably asked donors that related icons be made for them.

There are paintings of other important Esoteric Buddhist divinities at Dunhuang, which have not been discussed here in relation to donors, such as the 
Cintāmanicakrāvalokiteśvara or the Thousand-armed Mañjuśrī, the cults of which enjoyed great popularity locally. However, there are no surviving examples of paintings with donors of Cintāmanicakra, so a discussion of this theme has not been included here.

Finally, we can say with some confidence that based on the structural formats of many of the banner paintings, it is problematic to insist that they represent anything in the line of an 'orthodox' or exclusive Esoteric Buddhism. Only in a few isolated exceptions, such as in representations of Amoghapāśa, the Thousand-armed Avalokiteśvara, or the rudimentary Vajradhātu Maṇdala (and other mandalas), encountered in both the Mogao Caves and Yulin Caves, can we speak of iconographical forms - and by inference of the related rituals - that unmistakably signal Esoteric Buddhist practices in the more formal sense.

\section{Acknowledgments}

The author wishes to thank the anonymous rewiever for having pointed out various mistakes and inconsistencies in the original manuscript. 